\title{
The divine favour of the unworthy: When the Fatherless Son meets the Black Messiah
}

\begin{abstract}
Author:
Allan A. Boesak ${ }^{1}$

Affiliation:

${ }^{1}$ International Institute for the Study of Race, Reconciliation and Social Justice, University of the Free State, South Africa

Note:

Prof. Dr Allan A. Boesak

Theologian in Residence at the International Institute for the Study of Race, Reconciliation and Social Justice at Free State University and Extraordinary Professor of Theology at Stellenbosch University, South Africa.

Correspondence to: Allan Boesak

email:

boesak@mweb.co.za

Postal address:

Postnet Suite 285, Private Bag X15, Somerset West 7130, South Africa

Dates:

Received: 02 Aug. 2010 Accepted: 06 Aug. 2010 Published: 07 June 2011

How to cite this article: Boesak, A.A., 2011, 'The divine favour of the unworthy: When the Fatherless Son meets the Black Messiah', HTS Teologiese Studies/ Theological Studies 67(1), Art. \#933, 9 pages. DOI: 10.4102/hts.v67i1.933
\end{abstract}

(C) 2011. The Authors. Licensee: OpenJournals Publishing. This work is licensed under the Creative Commons Attribution License.
This article engages with Andries van Aarde's 2001 work on the historical Jesus, Fatherless in Galilee: Jesus as Child of God. It poses the question whether Van Aarde succeeds in overcoming the shortcomings of Western, Euro-centric, male dominated scholarship and making a different kind of conversation with non-Western Christians possible. The article explores the new ways in which Van Aarde speaks of the historical Jesus and interrogates the consequences of his main thesis, namely that to understand the historical Jesus properly, one needs to understand the most determining fact of Jesus' life, specifically his fatherlessness. The article finds that Van Aarde's fatherless Jesus opens up heretofore unexplored possibilities for the ongoing discussion with liberation theologies, in particular Black liberation theology. However, it raises the question whether Van Aarde does justice to his own new insights by interacting with Western theological scholarship alone. The fatherless Jesus and the Black Messiah meet in South Africa, where the cause of the fatherless Jesus has been so shamefully betrayed and where the divine favour of the Black Messiah needs to be gloriously embraced.

\section{Fatherless in Galilee}

In 2001, Andries van Aarde published his Fatherless in Galilee: Jesus as Child of God, one of the most fascinating books I have read in a long time. It is the work of a consummate New Testament scholar, in itself a greater tribute to Van Aarde's life and work than any attempt at a Festschrift can ever be. The book is a careful study of the latest quests in the search for the historical Jesus, the long endeavour since the groundbreaking work of Albert Schweitzer and explains Van Aarde's own quest to discover who God is, how Jesus is related to God, how much we can know about Jesus and, besides a series of important questions, to discover above all 'what is at stake when one says that [the] study of the life of Jesus is important' (Van Aarde 2001:1).

Right at the start Van Aarde (2001) makes two crucial points that determine his work, as well as the wider framework of his understanding and interpretation. In the first place, he admonishes us that it would be wise to take Seán Freyne's advice to heart:

I am convinced that the present 'third wave' quest for the historical Jesus is no more free of presuppositions than any of the other quests that went before it. Nor could it be otherwise, no matter how refined our methodologies. If we are all prepared to say at the outset what is at stake for us in our search for Jesus ideologically, academically, personally - then there is some possibility that we can reach an approximation to the truth of things, at least for now. Even that would be adequate.

(Van Aarde 2001:3)

Van Aarde (2001) is therefore upfront and this is the second point, he regards his experience as crucial to his theological reflections:

The 'situated discourse' of this book is not only a matter of ideological and academic concern, but one of personal engagement. In my own journey I long ago found great pleasure in knowing Jesus. My voyage began with a strenuous relationship with my father, but as a child and adult I experienced the warmth of the believing community.

(Van Aarde 2001:4)

Van Aarde takes us through the whole trajectory of the most recent research in Biblical scholarship, but the focal point of his research is to demonstrate that Jesus grew up fatherless and that Joseph, the father of Jesus, should probably be seen as a legendary figure (Van Aarde 2001:4). In antiquity, the consequences of this were vast: he would have been excluded from being called a 'child of Abraham', that is a child of God; access to the court of the Israelites in the temple would have been denied to him and he would have been excluded from the privilege of being given a daughter in marriage (Van Aarde 2001:4). Van Aarde shows how Jesus' fatherlessness is contextualised within a defamatory campaign that focuses on alleged illegitimacy (Van Aarde 2001:5).

He explores the meaning of the 'stigma of being fatherless' in antiquity in social-scientific terms, whether in Sepphoris, Galilee or Pompeii, Italy. He engages arguments surrounding the virgin 
birth, the life and ministry of Jesus, the development of the dogma of the 'two natures' of Jesus as human and divine and underlines the 'subversiveness of Jesus' cause' (Van Aarde 2001:5).

Putting on 'a different thinking cap', Van Aarde (2001:30) wants neither to be bound by the so-called 'third quest' in the historical Jesus research nor to the 'renewed quest', a distinction so rooted that N.T. Wright believes there is 'no third option' (Van Aarde 2001:32-33). Yet for Van Aarde there is a third option: 'It is not a middle of the road stance', Van Aarde insists, 'but an uncommitted journey where both Jesus' non-apocalyptic response to Jewish eschatology and Mark's apocalyptic interpretation are not anachronistically understood', for the 'cause of Jesus' challenges him to 'also consider the faith assertions that are found in the Gospel of Mark' (Van Aarde 2001:33). As I understand Van Aarde, this means that he will learn from whatever results scholarship offers, but is not willing to entertain a forced dichotomy between the historical Jesus and the 'Jesus of faith'. The Jesus confessed by the believing community is more than (merely) a historical figure such as Aristotle, Plato, or Alexander the Great. He is confessed as the Messiah of Israel, as Lord of the world, as the Child of God, as God. This Jesus is the Jesus of faith, in contradistinction to, yet irrevocably bound with, the Jesus of history (Van Aarde 2001:8 [original emphasis]).

Van Aarde's interest in historical Jesus research is neither born from neo-orthodoxy nor from neo-liberalism: 'For me, it is a matter of urgency to prioritize and contextualize the sources that could lead to Jesus' (Van Aarde 2001:33). The 'subversive and dangerous memory of Jesus' compels us to take seriously both the context of the historical Jesus and the context of the believing community.

Van Aarde's (2001:38) 'third way' is a 'Christology from the side'. A 'Jesus from above' describes the conciliar debates about Jesus as a figure who descended from heaven and was incarnated on earth - a Jesus who has been confessed as 'true God' and 'true man' [sic]. A 'Jesus from below' refers to modern biblical scholarship where the focus is 'squarely on the humanity of Jesus'. Both these approaches represent a 'vertical classification', a perspective on the person of Jesus, which is 'chiefly, if not exclusively, concerned with symbols of power or force'. 'Jesus from above' reflects Christian tradition only after the time of Constantine, when hierarchy became the expressive social structure with power or force the primary concern. 'Jesus from below' expresses 20th century concerns with the relationship between the natural and the supernatural and the possibility of transcendence in a secular world (Van Aarde 2001:38). Yet, Van Aarde argues, within Christian groups before Constantine, the chief expressive social dimension for non-Roman and Roman nonelite was not vertical but horizontal - 'from side-to-side' (Van Aarde 2001:38).

\section{This argument means that Jesus:}

as a first-century Israelite from Galilee should be studied like other historical persons and should not be regarded as absolutely unique, whatever material is available and by applicable methods and models.

(Van Aarde 2001:38)

Van Aarde (2001) concludes:

Jesus' fatherlessness is probably a historical fact that should be taken into account when one considers his social identity, his non-patriarchal ethos, his behaviour toward women and children, and especially his trust in God as his Father.

(Van Aarde 2001:15)

Nonetheless, this Jesus, who was not just fatherless on earth, but fatherless in Galilee, is Child of God.

Putting on this 'different thinking cap' indeed allows Van Aarde (2001:30) to effectively pursue his central thesis - that of the fatherlessness of Jesus, dealing along the way with the thorny issues of the virgin birth, the meaning of Jesus' baptism by John the Baptist and Jesus as the 'Son of God'. His central thesis resonates strongly with the Jesus of Black liberation theology. Jesus, the son of Mary, grew up fatherless in Galilee of the Gentiles and had to deal with the scandal and uncertainty of what that meant. He was: 'the peasant boy who probably became a carpenter and then, definitely, a revolutionary teacher and compassionate healer' (Van Aarde 2001:73); the discredited, dishonoured one, resonates strongly with Black liberation theology's Jesus. So too, does his understanding of and emphasis on the consequences of this status of Jesus in his own historical context.

This raises two critical questions: does it lead to a better, not just different, understanding of the historical Jesus for us today and does Van Aarde overcome the shortcomings of Western, Euro-centric, male dominated scholarship, leading to a different and better kind of conversation with non-Western Christians? This is the persistent question that emanates from liberation theology in all its forms, (Hispanic liberation theology, feminist theology, Womanist theology e.g.) but for the purposes of this contribution, specifically Black liberation theology. That that question can no longer be ignored or denied by Western scholarship can be seen by the growing body of studies (Cleage 1969; Cone 1969, [1975] 1997, 1984, 1986; Wilmore, [1973] 2006; Boesak 1977, 1984, 1987; Hopkins 1993, 2005; Weems 1988; Felder 1991, 1992; Townes 1993).

Already Dietrich Bonhoeffer (1971) has thoroughly questioned the concepts 'from above' and 'from below', giving 'from below' a totally different meaning than modern Western scholarship could, or would, allow:

We have for once learnt to see the great events of history from below, from the perspective of the outcasts, the suspects, the maltreated, the powerless, the oppressed, the reviled - in short from the perspective of those who suffer.

(Bonhoeffer 1971:17)

The point Bonhoeffer (1971:17) makes is that personal suffering (which one takes upon oneself for the sake of justice, in solidarity with and in identification with the weak and oppressed) is 'a more effective key, a more rewarding principle for exploring the world in thought and action 
than personal good fortune'. The experiences of suffering in thought and action for the sake of justice allows one to see 'from below' (from the perspective of those who suffer) and this is "beyond any talk of "from below" or "from above".

The gift of Bonhoeffer, both through his theology and his personal experience, was to raise fundamental questions about the validity of 'conciliar debates' about Constantinian concepts of and 20th century concerns with Jesus, the natural and supernatural and the possibility of transcendence in a secular world. It is a telling commentary though, that this has remained, despite Bonhoeffer, the dominant trend in a European-centered theological discourse, which liberation theologians experience as a colonial, oppressive, exclusivist epistemology and practice. Does Van Aarde, seeing his point of departure in the main thesis of his study, overcome this? Does Van Aarde's 'side to side' approach (which rejects the 'from below' of liberal theology), take us closer to Bonhoeffer's 'from below' and via Bonhoeffer closer to Black liberation theology's 'from underneath' and the Black Messiah?

Van Aarde refuses to be defined by either neo-orthodoxy or neo-liberalism and he is absolutely right. Such a depiction would do him grave injustice. Yet, even with Van Aarde's self-acknowledged self-understanding, his honesty about the impact of intensely personal experience on his Jesus study, the question arises: is the distance qualitatively strong enough if nonetheless the only sources for this 'different cap' remain those of Western, Eurocentric Enlightenment?

Would Van Aarde's historical Jesus have looked and acted more different still if Van Aarde had taken more seriously the results of scholarship emanating from Black liberation theology? If he had taken into account the Jesus of suffering and liberation as seen through the eyes of and encountered in the lives of the outcasts, the suspects, the maltreated, the powerless, the oppressed and the reviled - the eyes of those who suffer? And what kind of conversation would emerge, with what kind of results for doing theology in South Africa and the world today? Simply put, what would happen if Van Aarde's fatherless Jesus met Black liberation theology's Black Messiah? This is what intrigues me in Van Aarde's captivating study and these are some of the questions I will try to explore in this ongoing conversation with Andries van Aarde.

\section{Recognising the depoliticised Jesus}

One of the main problems with New Testament scholarship, as it emanated from and was driven by the European Enlightenment, argues Richard A. Horsley, forerunner of a new wave of New Testament research, is its failure to understand that the historical context Jesus lived in and responded to, was the reality of the Roman Empire. Acknowledging that reality, Horsley argues, opens an entirely new way of doing New Testament studies and simultaneously allows us new insights into the historical Jesus.
Not only does the 'Enlightenment reduction of reality to what fit the canons of reason and Nature' leave theologians embarrassed about the Christian Gospels as sources for the historical Jesus, but, Horsley (2003:55; see Carter 2001:1¹) states that 'recent interpreters of Jesus still focus primarily on the sayings of Jesus isolated from literary context, and this also from historical social-political context' (2003:56).

This has produced a less clear, if not distorted picture of the world of the New Testament, the contexts of the first Christian communities and of the historical Jesus. The depiction is that of a 'domesticated Jesus', Horsley (2003:6) writes, 'reduced to merely a religious figure' and 'since by definition empire is political, a Jesus who is merely religious has no relevance to or implications for empire'.

But, learning from other disciplines, especially non-Western scholars 'who press for a hearing of different perspectives, Biblical Studies more generally is also discovering the importance of imperial relations, particularly its own connection with modern empire' (Horsley 1997:2). This discovery has forced some scholars to rethink several assumptions about the context of the New Testament writings and the historical Jesus which have led to fundamental misunderstandings: a depoliticised Jesus, a depoliticised Judea and Galilee and a depoliticised Roman Empire (Horsley 2003:11-12). ${ }^{2}$

Whilst the major problem with the standard interpretation of the historical Jesus is the depoliticisation practiced in Western Christian theology and established New Testament studies in general, there are other seriously limiting factors, writes Horsley (2003) and he identifies those as 'failures':

Most important among these are the failure to investigate, in as precise terms as possible, the particular historical conditions in which Jesus acted, the failure to consider the social form of the relationship between Jesus and those who responded to him, and the failure to investigate in as precise terms as possible the cultural tradition out of which he and his followers operated.

(Horsley 2003:13)

Small wonder then, that this process of depoliticisation has reduced Jesus 'to a relatively innocuous religious teacher' (Horsley 2003:13) or 'most recently in the guise of a wisdom teacher' (Horsley 2003:6).

Van Aarde's Jesus is clearly not an 'innocuous wisdom teacher' or mere religious figure. No, his Jesus was born to a single mother, lived and worked in Galilee, 'multilingual, inhabited by pagans and Israelites, many of mixed marriage heritages upon whom the Judeans looked down'. Visiting Judean priests came to teach and enforce the purity laws of

1.Carter (2001:1) puts it as follows: 'The approach to Matthew's Gospel is not the standard one, and challenges the dominant paradigm or way of reading Matthew's Gospel. The conventional scholarly way of reading this Gospel over the last century has been in relation to a synagogue with which Matthew's community is having or has been in relation to a synagogue with which Matthew's community is having or has had a bitter dispute... I do think (this approach) is too limited. It turns the Gospel into an exclusively religious work, concerned only with the religious questions and
personal matters'.

2.Horsley makes a very strong and in my view entirely convincing case identifying key, interrelated factors in this process of 'depoliticisation' through which interpreters 'tend to ignore, obscure, or trivialize the broader political situation in which [Jesus] was operating'. 
the sacred writings and Jerusalem authorities came to collect the temple taxes from impoverished people who tried to live according to ancestral traditions. These were peasants who survived on small pieces of land, landless tenant farmers who worked for absentee landlords in the cities, incurring huge debts, whilst some were forced off their land and turned to carpentry. Bandits, outcasts and rebels escaped to the mountains and found shelter in caves: 'This is the "Galilee of the Gentiles" where people lived in darkness. Somewhere there, Jesus is to be found ... He was a revolutionary and healer, teacher and helper' (Van Aarde 2001:75).

Thus situating Jesus as 'fatherless in Galilee' is crucial and Van Aarde is correct in doing so. This 'revolutionary' comes to us almost exclusively by way of Jesus' fatherlessness and the consequences thereof in early 1st century Judean society. The political significance of this is lost. The 'darkness' in which the Galileans lived was surely not simply 'spiritual', but darkness caused by oppression, exploitation, poverty, powerlessness and exclusion. There is mention of the social, economic and political situation of people at the time of Jesus, but hardly in relation to the reality of the Roman Empire or the political context of synagogue leaders and temple authorities in their collaboration with the Romans.

The tensions with temple authorities are focussed on the marginalisation of and scandal inflicted upon Jesus because of his suspected illegitimacy, rather than because of Jesus' stance regarding the ruling elites and the political consequences of his life and teachings. Thus, for instance, Van Aarde (2001:78) concludes that Jesus was crucified by the Romans 'after an outburst of emotion at the outer temple square', seemingly completely ignoring the political fact that Jesus was executed by order of the Roman governor and that he was killed by crucifixion, a form of execution that the Romans used to intimidate subject peoples by publicly torturing to death their rebel leaders. ${ }^{3}$ It was an effective form of rule by fear through intimidation and terror.

Is Van Aarde continuing the Western tradition of interpretation which created a depoliticised Jesus? His Jesus is decidedly less political than the Jesus emanating from Horsley's school of thought and the Black Messiah we meet in black liberation theology whose cause is the liberation of the poor and oppressed. However, it is a curious development and in my view not the logical conclusion of the possibilities Van Aarde's line of thinking itself opens up. At the end of his very helpful 'picture of Jesus' Van Aarde (2001:78), in reference to the two events that shape the life of Jesus, his birth and his baptism, concludes that 'what comes before and after Jesus at thirty seems to be his fatherlessness' - exclusively. He does concede however, that it cannot be

3.'The Romans deliberately used crucifixion as an excruciatingly painful form of execution by torture (basically suffocation) to be used primarily on upstart slaves and rebellious provincials' (Horsley 2003:28-29). Van Aarde (2001:127) takes this and rebellious provincials ' 'status- envy' that eventually caused his death: 'Calling God father and negating the importance of patriarchy goes hand in hand. This disposition amounts to redefinition of the whole system of holiness... Eventually it led to his killing by the Roman authorities'. But see Horsley (2003:6): 'If nothing else, then the fact that he was crucified... should lead us to take another look'. proved that this image is representative of 'the real Jesus' even though this is, for him, the 'Jesus of history and the Jesus of faith' (Van Aarde 2001:78) and it is this we shall have to further explore.

\section{The Jesus of history and the Jesus of faith}

There are several reasons why the insights of the Horsley school of thought are so important to our discourse. Firstly, they recognise the crucial nature of the historical context of Jesus and his times in terms of the realities of empire. That is a major paradigm shift that allows for a totally new understanding of the New Testament writings. These writings can no longer be read as mere 'religious' writings and the tensions depicted in them are not simply tensions between 'the Jews' and the emerging Christian community. Secondly, they recognise the failures of Western scholarship in its interpretation of the sacred Scriptures. Jesus can no longer be reduced to a religious teacher who uttered isolated sayings and parables relevant only to individual persons and the Scriptures can no longer be detached from the living, breathing, suffering communities for whom they were written and amongst whom they emerged. Thirdly, in recognising the imperial context of Jesus and his followers, they recognise at once the imperial realities of our day and what that means for both the beneficiaries and the victims of empire. '[After 9/11] we can no longer rest comfortably with such domesticated pictures of Jesus', writes Horsley. He continues as follows:

We can no longer ignore the impact of Western imperialism on subordinated peoples and the ways in which peoples whose lives have been invaded sometimes react. The 'coincidental' historical analogy is too disquieting ...

(Horsley 2003:6)

Fourthly, the acknowledgement of non-Western scholarship in its critique of Western scholarship, the new perspectives that this critique offers and the impact of that critique on their interpretation of Scripture and their understanding of ancient and current political situations and brings a definite shift in our theological discourse. It is not simply a paternalistic 'reaching out' to non-Western thinking, it is coming closer to accepting the demand to 'reconfigure the very scaffolding of the discourse' itself, as Dwight Hopkins (2005:20) formulates it.

Van Aarde's Jesus of history and of faith, the revolutionary, healer, teacher and helper has long been at the heart of Black Christianity. However, this truth did not come automatically to Black people in their encounter with the Christian faith; it is a truth they had to discover themselves despite the Christianity White people brought. For, as Vincent Harding writes, speaking for all conquered, colonised and enslaved people:

We first met this Christ on slave ships. We heard his name sung in praise while we died in our thousands, chained in stinking holds beneath the decks, locked in with terror and disease and sad memories of our families and homes. When we leaped from 
the decks to be seized by sharks we saw his name carved in the ship's solid sides. When our women were raped in the cabins, they must have noted the great and holy books on the shelves. Our introduction to this Christ was not propitious and the horrors continued on America's soil.

(Boesak 1977:41)

Black Christians also came to understand the truth, which was spelt out so clearly by Helmut Gollwitzer (1974) as he soberly ponders the history of European Christianity and those great events that so decisively shaped that history:

Whether Rome won or Wittenberg or Geneva; whether it was to be justification through good works or by faith; whether the Decrees of Dordt or the statements of the Remonstrants were to become the official church doctrine; whether Cromwell or Charles I would be victor - for the red, yellow and black people of the world this was all irrelevant. This had no bearing whatsoever on their situation ... Nothing of all this would stop the capitalistic revolution as the revolution of the white, Christian, Protestant peoples that would spread all over the world to open the era of slavery which even today (albeit not in the same form) is not yet ended. ${ }^{4}$

(Gollwitzer 1974:45-46; cf. Boesak 1977:31)

Yet, Black Christians needed to make the distinction Frederick Douglass made between:

The religion of our blessed Saviour ... which comes from above, in the wisdom of God which is first pure, then peaceable, gentle ... without partiality and without hypocrisy ... which makes it the duty of its disciples to visit the fatherless and the widow in their affliction. I love that religion ... It is because I love this religion that I hate the slave-holding, the woman-whipping, the mind-darkening, the soul-destroying religion that exists in America ... loving the one I must hate the other; holding to one I must reject the other.

(see Boesak 1977:5)

To learn to love this religion, Black people have embraced Christianity, not as it was delivered to them by segregated White churches:

but as its truth was authenticated to them in the experience of suffering, to reinforce an ingrained religious temperament and to produce an indigenous religion oriented to freedom and human welfare.

(Wilmore 2006:25)

This understanding came through intense struggle with Scripture and the encounter with God in the Black experience of suffering and struggle for freedom. In that experience the God of the Bible, who is a God of slaves, of justice and freedom, is revealed as the God of Jesus Christ. And this Jesus is not just a transcendent being - he is the One who in his incarnation has become them, took upon himself their reality of suffering, identified with their humiliation, their hunger, their poverty, their misery, their enslavement, their Blackness. But he is also the One who promises liberation from slavery and captivity, healing from sickness, restoration of their humanity and resurrection from death.

It is not that the great debates of the church had simply passed Black Christians by. 'I respect what happened at

4. How Black Reformed Christians endeavoured to deal with this reality in their efforts at appropriation of the Calvinist Reformed tradition in South Africa I have discussed elsewhere (see Boesak 2010:289-301)
Nicea and Chalcedon and the theological input of the Church Fathers on Christology', says James Cone (1997:13), 'but that source alone is inadequate ... the homoousia question is not a black question'. ${ }^{5}$ So following Cone, black Christians asked different questions and came to different conclusions:

The Jesus of Nicea, Chalcedon and the ancient creeds - Light from light, begotten, not made, of one substance with the Father - was beautiful, but so painfully remote, untouched and unmoved by human misery caused by injustice and inhumanity. Indeed, in the rendition of the European Renaissance, this Jesus was too beautiful, too aloof, too aristocratic for the pain, filth and ugliness of slavery and degradation, too light for the darkness of our misery as black people. The Jesus of Constantinian Christianity, without the crown of thorns, but with the crown of laurels, with his wounded hands holding the sword and the standard of the empire, in whose holy name we were caught and chained, disrobed and shamed, flayed and slaughtered, disowned, unnamed and unmade and finally baptized - that Jesus bore no resemblance at all to the Human Son.

(Boesak 2009:39)

The Human Son is the Jesus of history and of faith encountered in the Scriptures and in the Black experience. In the dialectic of Scripture and the Black experience, Black people immediately recognised the:

gross inconsistency between the allegation that this all-powerful God of the whites could care so much about their eternal salvation while remaining indifferent to the powerlessness and wretchedness of their condition.

(Wilmore 2006:32-33)

Their understanding of Scripture taught them that:

The God who demanded their devotion, and from whom came the spirit that infused their secret meetings and possessed their souls and bodies in the ecstasy of worship, was not the God of the slave master, with his whip and gun, nor the God of the plantation preacher with his segregated services and injunctions to servility and blind obedience.

(Wilmore 2006:33)

The New Testament describes Jesus as the oppressed One who came to liberate the poor, the hungry, the naked, the widows and orphans, the oppressed and the afflicted; those who cannot defend themselves against the powerful. This is how he announces himself (Lk 4:16-18) and this is how he reveals himself in his work on earth and in the experience of Black people. Accordingly, James Cone (1997) writes:

Jesus Christ is not a proposition, not a theological concept which exists merely in our heads. He is an event of liberation, a happening in the lives of oppressed people struggling for political freedom. Therefore, to know him is to encounter him in the history of the weak and the helpless. The convergence of Jesus Christ and the black experience is the meaning of the Incarnation.

(Cone 1997:32-33)

Hence, Black theology does not separate the reality of the historical Jesus from the reality of his presence in the world 5.Cone (1997:13) adds: 'While not diminishing the importance of (Martin) Luther's theological concen, I am sure that if he had been born a black slave, his first question would not have been whether Jesus was present at the Lord's Table but whether he was really present at the slave's cabin, whether slaves could expect Jesus to be with them as they tried to survive the cotton field, the whip, and the pistol'. 
today:

Yahweh, who Israel had learned to know 'through what he had done' with and for his people, has now made himself known through his Son, through what Jesus, in his turn, was doing with and for people. Thus we understand John 14:9 to read, 'To have seen me (act) is to have seen the Father (act)'.

(Boesak 1977:41)

So the answer to the question, how close Van Aarde's 'Jesus of history' and his 'Jesus of faith' is to the Jesus of history and faith as expounded by Black theology and experienced in Black Christian life, depends on another question, namely 'Whose history? Whose faith?' That, in turn, might again depend on the question, 'Whose Jesus?'

\section{Whose Jesus?}

When Van Aarde (2001:6) says, 'My book is about the historical Jesus who filled the emptiness caused by his fatherlessness with his trust in God as his Father' and 'my own sense of fatherlessness propelled me toward my present Jesus studies' and again, 'I did, however, become existentially impelled by Jesus' fatherlessness because it addressed my own situation' and yet again, 'I have come to learn through my own experience who Jesus was and still is, child of God', he does a remarkable thing. It is rare in Western scholarship to give so much weight to personal experience in an intellectual endeavour. But already, in this admission, there is great resonance with one of Black theology's central assertions, that is, that the encounter with God in the Black experience is a legitimate source for theological reflection and that the theologian is exegete both of Scripture and of life (cf. Cone 1997:8). ${ }^{6}$

Van Aarde (2001:3) cautions that 'an image of Jesus can be either an alienation or and affirmation of the biblical model' and that the portrayal of Jesus 'is only a shadowy etching'. However, his captivating picture of Jesus shows how much the theme of fatherlessness shapes this picture and how close he comes to Black theology's Black Messiah (see Van Aarde 2001:177-178). It is not an 'alienation'.

Amongst other things, Van Aarde's Jesus was born out of wedlock, remained unmarried and had a tense relationship with his mother and siblings. He carried sinfulness that led to his association with John the Baptist and was homeless, leading an itinerant lifestyle. He defended fatherless children, patriarchless women and other outcasts and offended village elders by his subversive teaching and actions. He outraged Pharisees, Herodians, chief priests and elders in Jerusalem and critisised the manipulative ploys and misuse of hierarchical power of temple authorities. Crucified by the Romans, his body was not laid down in a family tomb. He was believed to have been taken up in the bosom of Father Abraham and was believed to be God's beloved child.

6.Cone (1997:8) puts it as follows: 'The theologian is before all else an exegete simultan that Scripture is not an abstract word, not mer. to be a the scripture is not an abstract word, not me those who are oppressed and humiliated in this world. The task of the theologian is to probe the depths of Scripture exegetically for the purpose of relating that message to human existence'.
All this affirms Van Aarde's central thesis of Jesus' fatherlessness. Much attention is given to 'the stigma of fatherlessness' and the social consequences of that fatherlessness - Jesus would have been excluded from being called a child of Abraham and access to the court of the Israelites in the temple would have been denied him because of his sinfulness. ${ }^{7}$ Van Aarde's Jesus was a person whose legitimacy and therefore (in the eyes of his detractors), his humanity was in doubt; a 'nobody' (Van Aarde 2001:60-61, 127), derisively called a 'Samaritan', a person of mixed race, looked down upon by the Judeans with a contempt well expressed by historian Josephus: 'With two races is my soul vexed; and the third is no nation: with the dwellers of Seir and Philistea, and with the foolish race that sojourns in Shechem'8 (Van Aarde 2001:60-61, 127).

\section{The divine favour of the unworthy}

What is striking about Van Aarde's Jesus is not just what is written but also what is left unsaid. It is without doubt a fascinating picture he paints, but it is startling, for example, that he does not point out the one salient feature about Jesus that characterises his entire mission and has enormous theological implications, in fact, without which every Jesus study is fatally flawed: Jesus' identification with the poor and oppressed. Jesus was poor, a child in a poor family who could not bring the prescribed sacrifice at his birth but instead the sacrifice of the poor, two turtledoves instead of the year-old lamb (Lv 12:6-8; Lk 2:21-24). He belonged to an impoverished people in Galilee, downtrodden, oppressed and exploited by the ruling elites in Jerusalem and the Roman occupiers (Boesak 1977:43-44). He came expressly for this reason: to preach good news to the poor, to liberate them from their captivity and to restore their humanity. He identified himself with the poor and with their struggle for liberation. In the Gospels, Jesus becomes the poor, the hungry, the naked, the imprisoned and the sick. In Black theology these are not mere spiritual connotations, but the actual conditions of people living with naked brutality and oppression (cf. Boesak 1977:42; Felder 1992:19). For us, the historical Jesus is the embodiment of God's preferential option for the poor.

Instead of ignoring them or mythologising them into meaninglessness, Black theology, as James Cone (1997) shows, understands Jesus' exorcisms as carrying out the theme of liberation of the poor, because freedom for the oppressed can come about only by overcoming the forces of evil:

[The scandal of Jesus] is that the exorcisms disclose that God in Jesus has brought liberation to the poor and the wretched of the land, and that liberation is none other than the overthrow of everything that is against the fulfillment of their humanity. The scandal is that liberation comes to the poor, and that the Gospel means liberation, and that it gives them the strength and the courage to break the conditions of servitude. This is what

7.Cf. chapters 4 and 5 .

8.Van Aarde (2001:91) explains it as follows: 'Samaritans are associated not with Samaria but with Shechem'. Reference is also made in the Testament of Levi, Chapter 7: 'From this day Shechem will be called the City of Fools' (see Van Aarde 2001:91). 
the Incarnation means. God in Christ comes to the weak and the helpless, and becomes one with them, taking their condition of oppression as his own and thus transforming their slaveexistence into a liberated existence.

(Cone 1977:71)

This same theme persistently characterises Jesus' life and work, for example, the temptation story (Mt 4:1ff; Mk 1:12-13; Lk 4:1ff). 'The heart of the matter', writes James Cone (1997:68-69), 'is Jesus' rejection of any role that would separate him from the poor'. Cone is right, but it is more. All the temptations offered to Jesus are the things that the Emperor boastfully claims: miracle provider for the masses, the arrogance of power and limitless imperial power itself. Jesus' identification with the poor is also the deliberate rejection of all imperial pretences and the things identified with imperial power, exposing it for what it is: the works of evil.

His actions were indeed subversive and offensive to the ruling elites, because he posed such a political threat to the privileged life they led, at the cost of the poor. Keeping in mind the realities of Roman occupation, the crippling taxes to prop up the military, the hierarchy in Rome and in the provinces, the vast system of patronage, the 'cultural projects' both by the Caesars and the client kings in Judea undertaken at the expense of the poor, the decades of revolt against this oppression and the terror and vengeance of Roman retaliation, it becomes unimaginable that Jesus was the only person unaffected by all this. ${ }^{9}$

In Black theology, Jesus' life and mission are paradigmatic of the inverted order of the kingdom of God that Jesus comes to proclaim and indeed represents. By 'inverted order' I do not mean that 'the last shall be first' in a general sense, nor in the sense of an apocalyptic divine retribution. Van Aarde (2001:154, 197) knows about this inversion too, but once again his Jesus is exclusively driven by his fatherlessness: 'By making the child, and not the father, the model for entry into the reign of God, the fatherless Jesus reversed the hierarchical assumptions that governed all of life' (Van Aarde 2001:154; cf. Countryman 1989:188). Jesus is partial to patriarchless women, that is women without the status accorded by being claimed by a man, therefore vulnerable and he acted in ways 'that women would': referring to himself as a 'servant', serving others, taking the last place at the table, forgiving wrongs, being compassionate and healing wounds (Van Aarde 2001:134). Finally, Van Aarde (2001:197) states bluntly that 'in many ways, Jesus acted like a woman'. But instead of exploring the enormous revolutionary possibilities these discoveries open up, it suffices to argue that Jesus did all of this because of his fatherlessness: 'As a fatherless figure, Jesus saw himself as the protector of fatherless children in Galilee, as well as of women who did not "belong" to a man'.

In Black theology, this inverted order is the intended purpose and work of the revolutionary Jesus. All this makes

9.See, for example, Horsley (2003). Van Aarde is not unaware of all this, but somehow does not draw these conclusions, for example pp. 128, 129, 130.
Jesus precisely who he was: the incarnated, liberating, humanising God taking sides with the oppressed. It is a persistent attack on the hierarchical structures that belittled, humiliated and exploited those who were given no status, did not count as fully human and were marginalised because of their powerlessness. Teaching that the gateway to God is not through a father figure on earth but through a child, especially if Van Aarde (2001:197) is right in asserting that the image Jesus invokes is not just any child, but a street child, an illegitimate child, is truly revolutionary.

Jesus was persistent in taking people from the periphery and deliberately placing them in the centre of attention. He did that in his dealings with children, but also with all of those that were regarded as without status and therefore without rights or dignity: the man with the withered hand $(\mathrm{Mk}$ 3:1-6) who had no 'right' to be in the synagogue is 'called forward' (placed in the centre) by Jesus; the woman suffering from haemorrhages is put in the centre whilst the privileged daughter of the powerful Jairus is allowed only to 'bookend' Jesus' healing of the woman (Mk 5:21-43). The daughter of the leader of the synagogue is restored to life, but remains 'little girl', whilst the poor, unclean and despised woman is called 'my daughter' by the man who is fatherless but makes every person a chosen and blessed child of God. The woman crippled for 18 years Jesus first heals, defends against the leaders of the synagogue and then calls 'a daughter of Abraham' (Lk 13:10-17). So the one with dubious parentage, who would not be allowed to call himself a 'son of Abraham' and who would be excluded from access to the court of the Israelites in the temple, claims the authority to rebuke publicly those whose authority is thus thoroughly put to question and calls this woman a 'daughter of Abraham'.

Like Jesus, these persons were all deemed unworthy by those who claimed worthiness by virtue of their birth, privilege, status, gender and power. They are all restored, reclaimed and redeemed by God. The unworthy are granted divine favour and that empowers them to reclaim their humanity.

Jesus was born in a stable, laid in a manger, amongst the dust, the animals and the dung, in screaming contrast to the palace. From the moment of his birth his legitimacy was in doubt and has the 'stigma of fatherlessness' clung to him as he grew up the child of a single mother. ${ }^{10}$ Black theology does not join the debate whether the angel in fact appeared to Joseph and instructed him about the name of Jesus. Rather we focus on a fact Van Aarde himself alerts us to: 'Apart from Jesus who is called "the Christ"', Josephus mentions at least twelve others called Jesus who played a part in the history of Israel during the period of Graeco-Roman domination. However, 'the vast majority of these people belonged to priestly and governing families' (Van Aarde 2001:6 footnote 8). Jesus, son of Mary, a 'bastard' and a 'nobody who would have no identity' (Van Aarde 2001:127) was the exact opposite, not even remotely

10.Van Aarde (2001:73) refers to what are called the 'Yeshua ben Pentera' traditions in the Talmud that refer to Jesus' illegitimacy, that he could be the child of anybody, the in the 2 nd century C.E. Justin responded to accusations of (the) rape (of Mary,
and the mother of Jesus). 
identified with the privileged oppressor elites. He was the One sent from God, the liberator of the oppressed, the defender of the poor and the helper of the helpless. It was not his name that distinguished him from the others 'who all played a role', but his self-understanding, his mission, his taking sides with those who were the victims of the very power structures that gave the others also named Jesus their status.

Whereas Van Aarde (2001:61) seeks explanations for the 'Son of God metaphor' in Greek-Roman mythology, Black theology asks, with Jane Schaberg, 'But why could Jesus not be the Son of God and son of an unknown or even son of a nobody?' This is precisely why it is too scandalous to contemplate, but therein lies the power and the glory of the incarnation.

Black theology understands the 'shame' and 'embarrassment' of Jesus' fatherlessness, not only in the sense of Steve Biko's (1986:56) 'unwanted step-children of a God whose presence they cannot feel', but in the actual life experience of millions of township children and single mothers. It understands the stigma of his racial identity, being called a 'bastard' and a 'Samaritan', a child of the Mamzerim, of uncertain parentage (Van Aarde 2001:92), excluded from the privileges of the temple, being regarded as 'sinful' because he did not conform to the criteria of acceptability laid down by the powerful hierarchical structures of the temple authorities. After all, we have heard how White Christians spoke of us. As British scientist, Robert Knox asked:

What signify these races to us? Who cares particularly for the Negro, or Hottentot, or Kaffir ... Destined by the nature of their race to run, like animals, a certain limited course of existence, it matters little how their extinction is brought about. ${ }^{11}$

(in Magubane 1999:26)

All this and much more besides, has been part of the Black experience. And Jesus, in becoming human, took upon himself the shame and stigma that were inflicted upon Black personhood, identified with them in their struggle for human dignity and restored to them their status as children of God. This is what the incarnation, in contrast to European racism, signified to us and what Black personhood signified to God. And Jesus is the Son of God, not despite the stigma, the sinfulness and the servanthood, the effeminate acts of compassion and forgiveness, 'acting like a woman', but precisely because of it. 'Calling God father and negating the importance of patriarchy' is not a result of 'status-envy' caused by fatherlessness (cf. Van Aarde 2001:127), but a radical, deliberate and direct onslaught on the rules, the language and the realities that upheld the unjust, unequal and oppressive, hierarchical and patriarchal societal structures that kept the ruling elites in power. Jesus' words and actions are not the incidental by-product of a psychological condition and neither is it solely the consequence of fatherlessness. It is a deliberate choice. It is Jesus' understanding of his mission, as he interpreted it, in light of the words of the prophet Isaiah (Is 61:1, 2; Lk 4;16ff) and this is who he understood God to be, the One he called 'father': 'For I, the LORD, love justice' (Is 61:8). This is who he is.

11.From Robert Knox's May 1847 lecture, 'The races of mankind: A philosophical inquiry into the influence of race over the destinies of nations'.
The scandal of the Incarnation is that this is who God chose to become. God reveals that it is in this Jesus from Galilee of the Gentiles, the One who has 'emptied himself' (Phlp 2:5-11), taking on the form of a slave, identifying with the humiliation, the pain, the debasement of slaves, the poor, women and children, in this love to the very end, that God has entered into the human story, demonstrating true power and majesty. The servant-slave, the emptied one, is Lord; the slave reigns (cf. Boesak 2005a:97-101).

It is as the runaway slave that Yahweh intervenes with Hagar in the wilderness 'on the way to Shur'; it is as the runaway slave that she is expressly spoken to and it is as the runaway slave that she is given the promise (Gn 16:10), so that the people in the household of Abraham would not forget her or deny who her son really is, so that the shame of her abandonment would be unmistakable and undeniable and the promise all the more significant (Boesak 2005b:1-28). Moses was given the task of leading God's people out of Egypt not whilst he was in a position of power in Pharaoh's household, but when he was:

on the run, deprived of his status as the son of the daughter of Pharaoh, and no longer able to exercise any of the power and privilege that came with that status.

(Amjad-Ali 2006)

And it is to the fatherless child that God declared: 'You are my Son, the Beloved; with you I am well pleased' (Mk 1:11). Such is the divine favour of the unworthy. As such, too, he is the Black Messiah. For us this statement is not metaphorical or iconological, it is Christological (cf. Cone 1997:122-126; Boesak 1977:41-45). ${ }^{12}$

\section{Conclusion}

Andries van Aarde's fatherless Jesus, the revolutionary who redefined the codes, systems and politics of holiness, broke down the barriers and undermined hierarchical structures to raise up those subjected to and denied by them; the subversive who restored the dignity of the downtrodden and shone God's divine favour upon those considered unworthy not only throws new light on the historical Jesus, but in my view indeed opens up heretofore unexplored possibilities for the ongoing discussion with liberation theologies and with black liberation theology in particular. It is an invaluable contribution to a new theological discourse.

Van Aarde (2001) is right:

To think that the journey [the quest for the historical Jesus] ended with the Old Quest or the New Quest or the Third Quest or even the Renewed Quest is to miss the reason for the search for Jesus.

(Van Aarde 2001:204)

12.Van Aarde's insistence on Galilee of the Gentiles as a place where people of mixed race lived, seems an invitation to far more seriously consider what, for example, Mexican Americans like Virgilio Elizondo and Fernando F. Segovia insist on, namely that Jesus was not only metaphorically black but indeed a person of on, namely that Jesus was not only metaphorically black but indeed a person of mixed descent: 'As a mestizo people, Mexican Americans represent a Galilee of the contemporary world, a modern example of a marginalized and oppressed people' (in De Young 2009:23). De Young (2009:34-36) speaks of Jesus as 'Afro-Asiatic': 'We can only confirm our earlier contention that Jesus, like other Jews in Palestin who had descended from the Hebrew people, was Afro-Asiatic', in South Africa's still race-obsessed colour coding, this would mean 'coloured' and it has enormous implications for politics and theology. 
The 'betrayal to the cause of Jesus' of which Van Aarde speaks, is not so much the thinking that the journey ended in the 4 th, 16 th or 20 th centuries, but that that journey can even continue without the discourse with liberation theology.

It is perhaps fitting that the fatherless Jesus and the Black Messiah should meet in South Africa, where the cause of the fatherless Jesus has been so shamefully betrayed and where the divine favour of the Black Messiah needs to be so gloriously embraced.

\section{References}

Amjad-Ali, C., 2006, Islamophobia or restorative justice: Tearing the veils of ignorance, Ditshwanelo CAR'AS, Johannesburg.

Biko, S., 1986, I write what I like, Harper \& Row, San Francisco, CA.

Bonhoeffer, D., 1971, Letters and papers from prison, ed. E. Bethge, Macmillan, New York.

Boesak, A.A., 1977, Farewell to innocence: A socio-ethical study on Black Theology and Black Power, Orbis Books, Maryknoll, NY.

Boesak, A., 1984, Black and Reformed: Apartheid, liberation and the Calvinist tradition, Orbis Books, Maryknoll, NY and Skotaville Publishers, Johannesburg.

Boesak, A., 1987, Comfort and protest: The apocalypse from a South African perspective, Westminster, Philadelphia, PA.

Boesak, A., 2005a, The tenderness of conscience: African Renaissance and the spirituality of politics, Sun Press, Stellenbosch.

Boesak, A., 2005b, Die vlug van Gods verbeelding: Bybelverhale van die onderkant, Sun Press, Stellenbosch.

Boesak, A., 2009, Running with horses: Reflections of an accidental politician, Joho! Publishers, Cape Town.

Boesak, A., 2010, 'At the heart of it all: Perspectives on the struggle for the relevance of the Reformed tradition in South Africa', Nederduits Gereformeerde Teologiese Tydskrif 51, 289-301.
Cleage, A., 1969, The Black Messiah, Andrews \& McMeel Inc., Fairway, KS. Cone, J.H., 1969, Black Theology and Black Power, Seabury, Minneapolis, MN. Cone, J.H., [1975] 1997, God of the oppressed, Orbis Books, Maryknoll, NY.

Cone, J.H., 1984, For my people: Black Theology and the black church, Orbis Books, Maryknoll, NY.

Cone, J.H., 1986, Speaking the truth, Eerdmans, Grand Rapids, MI.

De Young, C.P., 2009, Coming together in the 21st century: The Bible's message in an age of diversity, Judson Press, Valley Forge, PA.

Felder, C.H., 1992, Troubling biblical waters: Race, class and family, Orbis Books, Maryknoll, NY.

Felder, C.H. (ed.), 1991, Stony the road we trod: African American biblical interpretation, Fortress, Philadelphia, PA.

Gollwitzer, H., 1974, 'Schwarze Theologie', Evangelische Theologie 34, 43-69.

Hopkins, D.N., 1993, Shoes that fit our feet: Sources for a constructive Black Theology, Orbis Books, Maryknoll, NY

Hopkins, D.N., 2005, Being human - race, culture and religion, Fortress, Minneapolis, $\mathrm{MN}$

Horsley, R.A. (ed.), 1997, Paul and empire: Religion and power in Roman imperial society, Trinity, Harrisburg, PA.

Horsley, R.A., 2003, Jesus and Empire: The kingdom of God and the new world disorder, Fortress, Minneapolis, MN.

Magubane, B., 1999, 'African Renaissance in historical perspective', in M.W. Makgoba (ed.), African Renaissance: The new struggle, pp. 10-36, Mafube \& Tafelberg, Cape Town.

Schweitzer, A., 1968, The quest for the historical Jesus: A critical study of its progress from Reimarus to Wrede, Macmillan, New York.

Townes, E.M. (ed.), 1993, A troubling in my soul: Womanist perspectives on evil and suffering, Orbis Books, Maryknoll, NY

Van Aarde, A.G., 2001, Fatherless in Galilea: Jesus as Child of God, Trinity Press International, Harrisburg, PA.

Weems, R.J., 1988, Just a sister away: A womanist vision of women's relationships in the Bible, LuraMedia, San Diego, CA.

Wilmore, G.S., [1973] 2006, Black religion and black radicalism: An interpretation of the religious history of African Americans, Orbis Books, Maryknoll, NY. 